\title{
AEG-1 expression is an independent prognostic factor in rectal cancer patients with preoperative radiotherapy: a study in a Swedish clinical trial
}

\author{
S Gnosa ${ }^{1}$, H Zhang ${ }^{2}$, V P Brodin ${ }^{1}$, J Carstensen ${ }^{3}$, G Adell ${ }^{4}$ and X-F Sun ${ }^{*}, 1$ \\ ${ }^{1}$ Division of Oncology, Department of Clinical and Experimental Medicine, Faculty of Health Sciences, County Council of \\ Östergötland, University of Linköping, SE-58185 Linköping, Sweden; ${ }^{2}$ School of Medicine, Örebro University, SE-70128 Örebro, \\ Sweden; ${ }^{3}$ Division of Health and Society, Department of Medical and Health Sciences, Faculty of Health Sciences, Linköping \\ University, SE-58185 Linköping, Sweden and ${ }^{4}$ Department of Oncology, Karolinska University Hospital, SE-11883 Stockholm, \\ Sweden
}

Background: Preoperative radiotherapy (RT) is widely used to downstage rectal tumours, but the rate of recurrence varies significantly. Therefore, new biomarkers are needed for better treatment and prognosis. It has been shown that astrocyte elevated gene-1 (AEG-1) is a key mediator of migration, invasion, and treatment resistance. Our aim was to analyse the AEG-1 expression in relation to RT in rectal cancer patients and to test its radiosensitising properties.

Methods: The AEG-1 expression was examined by immunohistochemistry in 158 patients from the Swedish clinical trial of RT. Furthermore, we inhibited the AEG-1 expression by siRNA in five colon cancer cell lines and measured the survival after irradiation by colony-forming assay.

Results: The AEG-1 expression was increased in the primary tumours compared with the normal mucosa independently of the RT $(P<0.01)$. High AEG-1 expression in the primary tumour of the patients treated with RT correlated independently with higher risk of distant recurrence $(P=0.009)$ and worse disease-free survival $(P=0.007)$. Downregulation of AEG-1 revealed a decreased survival after radiation in radioresistant colon cancer cell lines.

Conclusions: The AEG-1 expression was independently related to distant recurrence and disease-free survival in rectal cancer patients with RT and could therefore be a marker to discriminate patients for distant relapse.

Colorectal cancer (CRC) is the third most common cancer worldwide and the fourth most common cause of cancer death (Ferlay et al, 2010). The type of therapy for CRC is depending on the tumour location and stage. Surgery is the mainstay of curative therapies for rectal cancer patients, but the pelvic localisation of the rectum leads to surgical limits and thereby to an increased risk of local recurrence and poorer overall prognosis (Påhlman, 2005).
As shown in several clinical studies, preoperative radiotherapy (RT) can potentially downstage the tumour, reduce the local recurrence, and improve the overall survival in rectal cancer patients (Swedish Rectal Cancer Trial, 1997; Kapiteijn et al, 2001). However, less than half of the patients achieve complete pathological response after preoperative chemoradiotherapy (Huerta et al, 2009). Having this in mind, it is essential to find molecular biomarkers as well as specific molecular targets to

*Correspondence: Professor X-F Sun; E-mail: xiao-feng.sun@liu.se

Received 20 June 2013; revised 27 March 2014; accepted 15 April 2014; published online 29 May 2014 
achieve improved pathological response and to give a better prognosis after treatment.

The oncogene, astrocyte elevated gene-1 (AEG-1, also known as Metadherin (MTDH), and LYRIC) was originally identified and cloned by subtraction hybridisation as a human immunodeficiency virus-1 (HIV-1)-inducible gene in human fetal astrocytes ( $\mathrm{Su}$ et al, 2002). The AEG-1 is markedly overexpressed in many types of cancers compared with normal cells, including oesophageal squamous cell carcinoma (Yu et al, 2009), gastric cancer (Jian-bo et al, 2011), CRC (Gnosa et al, 2012), hepatocellular carcinoma (Yoo et al, 2009), non-small-cell lung cancer (Song et al, 2009), neuroblastoma (Lee et al, 2009), breast cancer (Brown and Ruoslahti, 2004; Li et al, 2008), prostate cancer (Thirkettle et al, 2009), and renal cancer (Chen et al, 2010).

The AEG-1 is activated by the oncogene Ha-Ras through PI3K/ Akt leading to transcriptional upregulation of AEG-1 by c-Myc (Lee et al, 2006). Once expressed, AEG-1 can activate several oncogenic signalling pathways such as PI3K/Akt, MAPK, Wnt, RNA interference, and NF- $\kappa \mathrm{B}$ that are involved in proliferation, chemoresistance, invasion, angiogenesis, and metastasis (Sarkar et al, 2008; Lee et al, 2008; Emdad et al, 2009; Yoo et al, 2011). Recently, Zhao et al (2012) showed that AEG-1 affects the survival, DNA repair, and cell cycle distribution after radiation in a cervical cancer cell line.

However, so far no study has analysed the AEG-1 expression in correlation to the patient outcome in rectal cancer patients with RT. Therefore, we analysed the AEG-1 protein expression in rectal cancer specimens from 158 patients participating in a randomised Swedish rectal cancer trial of preoperative RT (Swedish Rectal Cancer Trial, 1997) as well as in five colon cancer cell lines and two normal colon cell lines. We then correlated the AEG-1 expression from the patient material with clinicopathological variables and with the expression of other biomarkers previously analysed at our laboratory on the same patient cohort. Furthermore, we analysed the impact of AEG-1 knockdown and overexpression on the survival after radiation in the colon cancer cell lines.

\section{MATERIALS AND METHODS}

Patient material. The study included 142 primary rectal adenocarcinomas (PT), 116 distant normal mucosa specimens (DN; 104 corresponding to the primary tumour, i.e., distant normal mucosa and primary tumour from the same patient) that were histologically free from tumour and taken from the margin of distant surgical resection, 77 adjacent normal mucosa specimens (AN; 74 corresponding to the primary tumour), and 48 lymph node metastases (MT; 42 corresponding to the primary tumour). The patients analysed in this study were from the South-East Swedish Health Care region and participated in the randomised Swedish rectal cancer trial of preoperative RT between 1987 and 1990 (Swedish Rectal Cancer Trial, 1997). Among the 158 patients, 83 underwent surgery alone and 75 received RT followed by surgery (Supplementary Figure 1). The required informed consent was given by all participants. The RT was applied to $25 \mathrm{~Gy}$ in 5 fractions within a median of 7 days (range, 4-12 days). None of the patients received chemotherapy before surgery. The surgery was performed after a median of 3 days (range, $0-11$ days). The mean follow-up period was 83 months (range, 0-193 months), and 54 patients died from the cancer. The median patient age was 69 years (range, 36-85 years). Other patient and tumour characteristics are presented in Supplementary Table 1.

Immunohistochemistry. Immunohistochemical analyses were performed as described previously (Gnosa et al, 2012). The primary rabbit polyclonal anti-MTDH antibody (Zymed, San Francisco, CA, USA) was dilution 1:300 in antibody diluent
(DAKO, Cytomation, Glostrup, Denmark). The immunostaining was scored by two independent observers based on the intensity and localisation without knowledge of clinicopathological and biological information. The intensity of staining was classified according to the following criteria: 0 (negative staining: $\leqslant 5 \%$ positive cells), 1 (weak staining: weak yellow), 2 (moderate staining: yellow-brown), and 3 (strong staining: brown), and the staining patterns were graded as cytoplasmic or nuclear. In the case of discrepant scoring results, a consensus score was reached after re-examination. For statistical analyses, negative and weak-stained cases were considered as low-expressing group, and moderate and strong staining as high-expressing group.

The expression of meninginoma activated protein (Mac30, Zhang et al, 2006), Ki-67 (Adell et al, 2001), FXYD-3 (Loftås et al, 2009), Lysyl oxidase (Lox, J Erler and X-F Sun, unpublished data, immunostaining was performed at Section of Cell and Molecular Biology, The Institute of Cancer Research, London, UK), and Livin (Ding et al, 2013) were determined by immunohistochemistry in our laboratory on the same patient samples as in the present study. The used cutoff points were the same as in the corresponding publication. The Lox expression was divided into two groups: (1) a low-expression group, including samples with negative staining for Lox in either the cytoplasm, the nucleus, or both and (2) a high-expression group exerting strong staining in the cytoplasm and nucleus.

Cell culture and ionising radiation experiments. The SW480 and SW620 cell lines were obtained from the American Type Culture Collection (Manassas, VA, USA). Human colon carcinoma cell lines KM12C and KM12L4a were kindly provided by Dr Isaiah J Fidler (M.D. Anderson Cancer Centre, Houston, TX, USA). The CCD-18Co cell line derived from human colon fibroblasts was a kind gift from Dr Richard Palmqvist (Umeå University, Umeå, Sweden). The CCD-841 CoN cell line was a kind gift from Dr Liang $\mathrm{Xu}$ (University of Kansas, Lawrence, KS, USA). The cell lines were maintained at $37^{\circ} \mathrm{C}$ and $5 \% \mathrm{CO}_{2}$ in Eagle's MEM (SigmaAldrich, St Louis, MO, USA) supplemented with $10 \%$ heatinactivated fetal bovine serum albumin (GIBCO, Invitrogen, Paisley, UK). For the KM12 cell lines, $2 \%$ vitamin solution (GIBCO) and $0.5 \%$ L-glutamine (GIBCO) were added. The HCT116 cell line was obtained from the core cell center (Johns Hopkins University, Baltimore, MD, USA) and was maintained in McCoy's 5A medium (Sigma-Aldrich) supplemented with $10 \%$ heat-inactivated fetal bovine serum albumin (GIBCO) at $37^{\circ} \mathrm{C}$ and $5 \% \mathrm{CO}_{2}$. Cells growing exponentially were harvested when $80 \%$ confluence was achieved. All cells were tested for Mycoplasma by using a commercially available PCR kit (PromoKine, Heidelberg, Germany). The morphology and growth rate of all cell lines were controlled during the whole experimental period.

To determine the effect of ionising radiation, cells were irradiated with a $6 \mathrm{MV}$ photon spectra using a linear accelerator (Clinac 4/100, Varian, Palo Alto, CA, USA). The cells were positioned below $3 \mathrm{~cm}$ PMMA, $105 \mathrm{~cm}$ from the photon source (the distance from the photon source to the PMMA surface was $100 \mathrm{~cm})$. The dose rate at the position of the cells was $4.8 \mathrm{~Gy} \mathrm{~min}^{-1}$ and the field size at SSD was $30 \times 30 \mathrm{~cm}$.

Western blot. Protein was extracted by lysis buffer containing $150 \mathrm{~mm} \mathrm{NaCl}, 2 \%$ Triton, $0.1 \%$ SDS, $50 \mathrm{~mm}$ Tris, $\mathrm{pH} 8.0$, and $10 \%$ Protease inhibitor cocktail (Sigma-Aldrich) and stored at $-20^{\circ} \mathrm{C}$. The protein concentration was determined by the colorimetric BCA protein assay reagent (Pierce, Woburn, MA, USA). Equal amounts of protein were loaded into pre-cast Mini Protean TGX gels (Bio-Rad, Hercules, CA, USA), separated by electrophoresis, and transferred to a Trans-blot Turbo PVDF membrane (Bio-Rad) using the Trans-blot Turbo transfer system (Bio-Rad). Membranes were blocked with $5 \%$ milk powder in TBS containing $0.1 \%$ Tween-20 for $1 \mathrm{~h}$ at room temperature and incubated with a primary polyclonal antibody rabbit anti-MTDH $(1: 1000$, Zymed) 
overnight at $4{ }^{\circ} \mathrm{C}$. The membranes were washed and subsequently incubated with the secondary HRP-conjugated polyclonal antibody goat anti-rabbit $(1: 2000$, DAKO) for $1 \mathrm{~h}$ at room temperature. Protein bands were detected using ECL plus Western Blotting Detection System (Amersham Bioscience/GE Healthcare, Piscataway, NJ, USA). To verify equal protein loadings, polyclonal rabbit anti- $\beta$-actin $(1: 5000$, Cell Signaling Technology, Danvers, MA, USA) was used as a loading control.

siRNA transfection. Cells were seeded in 6-well culture plates at a density of $1 \times 10^{5}$ cells per well in $2 \mathrm{ml}$ complete culture medium. After $24 \mathrm{~h}$, the cells were transfected by using DharmaFECT 2 (Thermo Fisher Scientific, Lafayette, CO, USA) with a siRNA pool containing 4 siRNAs targeting AEG-1 (Thermo Fisher Scientific, L-018531-01) or with a pool of 4 non-targeting siRNAs (Thermo Fisher Scientific, D-001810-10-20) at a final concentration of $25 \mathrm{~nm}$ according to the manufacturer's instructions. After $48 \mathrm{~h}$, fresh medium was added to the cells or the cells were seeded for followup experiments. The AEG-1 knockdown was confirmed by qPCR (Supplementary Materials and Methods) and by western blot (Supplementary Figure 2).

cDNA transfection. Cells were seeded in 6-well culture plates at a density of $1.5 \times 10^{5}$ per well in $2 \mathrm{ml}$ complete culture medium. After $24 \mathrm{~h}$, the cells were transfected with $1.5 \mu \mathrm{g}$ of either pCMV6-Neo (Origene, Rockville, MD, USA) or with pCMV6-Neo MTDH (Origene, NM_178812, CW101031) using X-tremeGENE 9 (Roche Diagnostic Corporation, Indianapolis, IN, USA) according to the manufacturer's instructions. After $24 \mathrm{~h}$, fresh medium was added to the cells or the cells were seeded for follow-up experiments. Upregulation of AEG-1 was confirmed by qPCR (Supplementary Materials and Methods) and western blot (Supplementary Figure 2).

Colony-forming assay. Cell viability was analysed using colonyforming assay. The cells were seeded $24 \mathrm{~h}$ before $0-6 \mathrm{~Gy}$ radiation in triplicates in 6-well plates with $2 \mathrm{ml}$ complete medium (500-1000 cells per well), and incubated at $37^{\circ} \mathrm{C}$ in $5 \% \mathrm{CO}_{2}$. Plates were examined to confirm that only single cells without aggregates had been plated. At respectively 6 (transient) and 10 days (stable) after radiation, the colonies were fixed with $4 \%$ formaldehyde for $15 \mathrm{~min}$ and stained with 5\% Giemsa in 95\% ethanol for $20 \mathrm{~min}$. Clones of a minimum of 30 (transient) and 50 cells (stable), respectively, were counted as one colony. The surviving fraction was normalised against the corresponding non-irradiated control cells.

Statistical analyses. McNemar's or $\chi^{2}$ test was applied to examine the significance of the differences in AEG-1 expression in normal mucosa, adjacent mucosa, primary tumour, and lymph node metastasis, as well as the association of AEG-1 expression with clinicopathological or biological variables. Log-rank test was used to examine the relationship of the AEG-1 staining with the relative risk for distant recurrence and the patient disease-free survival. Stratified log-rank test (Collet, 1994) was used for examining independency of AEG-1 expression from tumour stage in the relative risk of distant recurrence and disease-free survival. Survival curves were computed according to the Kaplan-Meier method. Student's $t$-test was used for examining the significance between treated and untreated cells. All cell line experiments were performed at least 3 times and data are presented as the mean \pm s.d. All tests were two sided, and $P$-values of $<0.05$ were considered as significant.
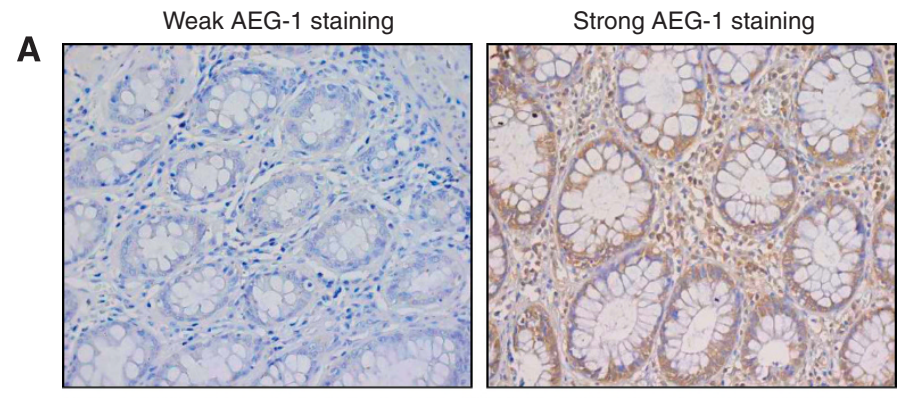

B
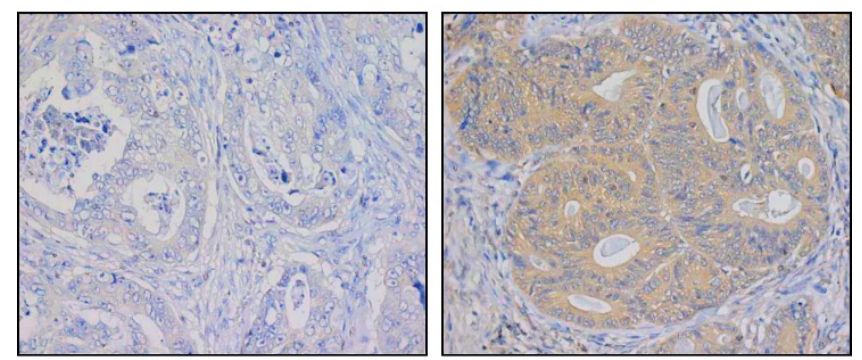

C
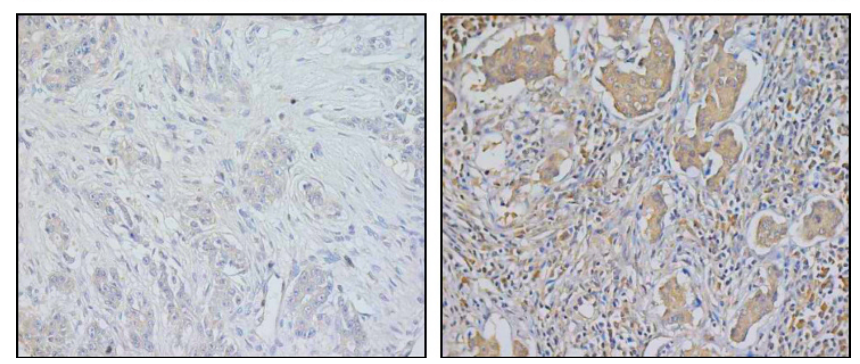

Figure 1. The AEG-1 protein expression determined by immunohistochemistry. The pictures are representative for weak and strong staining of (A) normal mucosa, (B) primary tumours, and (C) lymph node metastases. Magnification $\times 400$. 


\section{RESULTS}

AEG-1 expression during tumour progression in the non-RT and RT groups. The AEG-1 expression was analysed by immunohistochemistry in the distant normal mucosa, adjacent normal mucosa, primary tumours, and lymph node metastases from surgical resection samples. The AEG-1 expression was detected in the cytoplasm in all the sites, as well as in the nucleus in some samples from the distant normal mucosa and the adjacent normal mucosa. Examples of weak and strong cytoplasmic AEG-1 expression in the normal mucosa, primary tumours, and lymph node metastases are shown in Figure 1. Nuclear staining was not related to RT, gender, age, tumour stage, differentiation, or survival $(P>0.05)$, and therefore not considered for further statistical analyses.

The frequency of the AEG-1 expression in the different tissues in the non-RT and RT group is shown in Figure 2. In both the nonRT and RT groups, the AEG-1 expression in the primary tumour was significantly higher compared with the distant normal mucosa $(P<0.001$ and $P=0.01$, respectively) and the adjacent mucosa $(P<0.001$ and $P=0.022$, respectively; Figure $2 \mathrm{~A}$ and $\mathrm{B})$.

Evaluations of corresponding specimens revealed a higher AEG-1 expression in the primary tumour in both the non-RT and RT groups compared with the distant $(P=0.001$ and $P=0.019$, respectively) and the adjacent normal mucosa $(P=0.002$ and $P=0.043$, respectively). In this study, no differences in AEG-1 expression were found because of RT $(P>0.05)$ in the tissue samples. Furthermore, we analysed the AEG-1 expression in five colon cancer cell lines (SW480, SW620, KM12C, KM12L4a, and HCT116) and two normal colon cell lines (CCD18Co and CCD$841 \mathrm{CoN}$; Figure 2C). Compared with the normal cell lines we found a higher AEG-1 expression in the cell line SW620, and a substantial higher in the cell lines KM12C and HCT116.

AEG-1 expression in relation to clinicopathological and biological variables. Analyses of the AEG-1 expression in the primary tumours of the non-RT group revealed no relationship to gender, age, stage, differentiation, total recurrence (local and/or distant recurrence, $P=0.57$, Figure $3 \mathrm{~A}$ ), local recurrence, distant recurrence, or disease-free survival $(P>0.05$, Supplementary Table 2). In the RT group, the AEG-1 expression was higher in males compared with females $(P=0.046)$. Tumours of stage I-III with high expression of AEG-1 had a higher risk of developing total recurrence compared with tumours with low AEG-1 expression $(P=0.001$, Figure 3D). Moreover, in the RT group, high-AEG-1expressing tumours had a significantly higher distant recurrence rate compared with low-AEG-1-expressed tumours $\left(P=0.009, \chi^{2}=6.90\right.$, Figure 3E). Furthermore, high AEG-1 expression of stage I-III tumours was related to worse disease-free survival $(P=0.007$, $\chi^{2}=7.18$ Figure $\left.3 F\right)$. Stratified log-rank analyses showed that the statistical significance remained, independent of the tumour stage $\left(P=0.012, \chi^{2}=6.34 ; P=0.010, \chi^{2}=6.70\right.$, respectively). A similar trend was obtained when we analysed the all-cause mortality and the cancer-specific mortality $\left(P=0.07, \chi^{2}=3.28 ; P=0.018, \chi^{2}=5.79\right.$ respectively; data not shown). However, the group of patients receiving RT with low-AEG-1-expressing tumours was small and consisted of only 13 patients. There was no relationship between AEG-1 expression and age, stage, differentiation, or local recurrence $(P>0.05$, Supplementary Table 2$)$.

We next analysed the relationships of the AEG-1 expression with all biological factors examined on the same patient cohort at our laboratory before. Significant correlations are presented in Table 1 . In the non-RT group, AEG-1 was negatively correlated with the Mac30 expression $(P=0.021)$ and positively with the Ki-67 expression $(P=0.026)$. Tumours treated with RT showed a positive correlation of the AEG-1 expression with the FXYD-3 $(P=0.016)$ and Lox expression $(P=0.037)$. High AEG-1
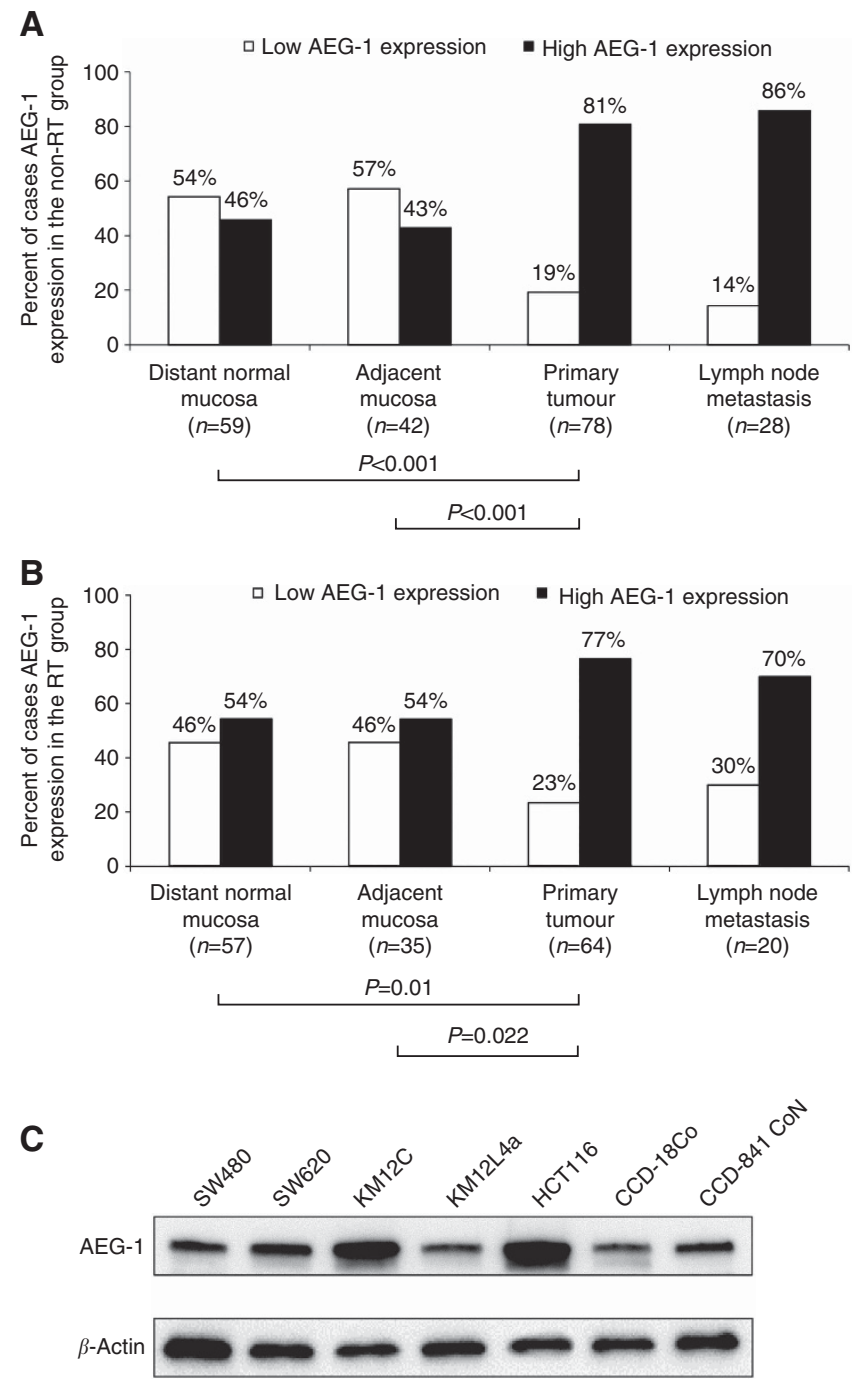

Figure 2. AEG-1 protein expression during tumour progression. The AEG-1 expression analysed by IHC in (A) the non-RT group and (B) the RT group was significantly higher in the primary tumour compared with the distant normal mucosa $(P<0.001$ and $P=0.01$, respectively) and the adjacent mucosa $(P<0.001$ and $P=0.022$, respectively).

(C) The AEG-1 protein expression examined by western blot in the colon cancer cell lines SW480, SW620, KM12C, KM12L4a, and HCT116, and normal colon cell lines CCD-18Co and CCD-841 CoN. The AEG-1 expression was higher in the cell line SW620 and substantially higher in the cell lines $\mathrm{KM} 12 \mathrm{C}$ and $\mathrm{HCT} 116$ compared with the expression in the normal colon cell lines CCD-18Co and CCD-841 CoN.

expression was related to Livin expression in the both non-RT group $(P<0.001)$ and RT group $(P<0.001$, Table 1$)$.

Clonogenic survival after radiation in AEG-1 down- and upregulated colon cancer cell lines. The AEG-1 expression was downregulated by transfecting the cell lines with a pool of four anti-AEG-1 siRNAs, and a non-targeting pool of four siRNAs was included as a negative control (Supplementary Figure 2). Clonogenic assay of AEG-1 knockdown cells after 2 Gy radiation showed a lower survival compared with the negative control in the cell lines KM12L4a (55\% vs 41\%; $P=0.007)$, SW480 (72\% vs 54\%; $P=0.21$ ), and SW620 ( $48 \%$ vs 35\%; $P=0.044$; Figure $4 \mathrm{~A}-\mathrm{C}$ ). In the cell line $\mathrm{KM} 12 \mathrm{C}$, the survival increased in the AEG-1 knockdown cells after 2 Gy radiation compared with the negative control (25\% vs $28 \%$; $P=0.041)$, whereas no change was seen in the HCT116 cell line 
A

$\square$ No recurrence - Recurrence

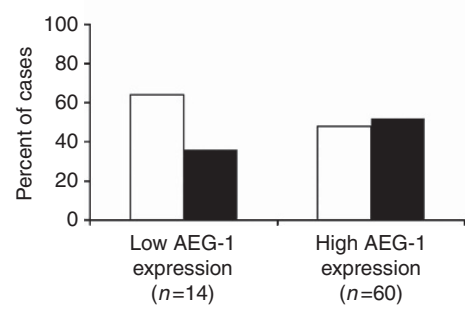

B

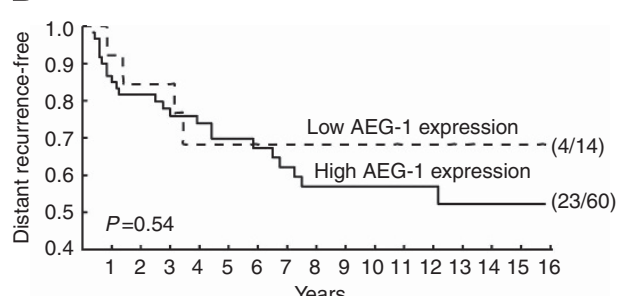

Years

\begin{tabular}{|c|c|c|}
\hline Patient at risk & 5 years & 10 years \\
\hline Low AEG-1 & 8 & 5 \\
\hline High AEG-1 & 32 & 17 \\
\hline Cumulative survival $(95 \% \mathrm{Cl})$ & & \\
\hline Low AEG-1 & $0.68(0.42-0.92)$ & $0.68(0.42-0.92)$ \\
\hline High AEG-1 & $0.69(0.57-0.81)$ & $0.57(0.43-0.71)$ \\
\hline
\end{tabular}

C

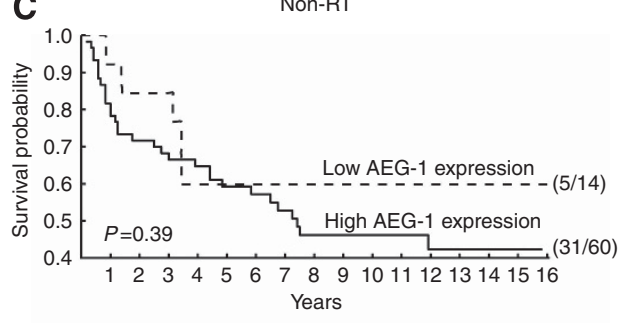

\begin{tabular}{|c|c|c|}
\hline Patient at risk & 5 years & 10 years \\
\hline Low AEG-1 & 7 & 5 \\
\hline High AEG-1 & 33 & 17 \\
\hline Cumulative survival $(95 \% \mathrm{Cl})$ & & \\
\hline Low AEG-1 & $0.60(0.38-0.88)$ & $0.60(0.38-0.88)$ \\
\hline High AEG-1 & $0.59(0.46-0.72)$ & $0.46(0.32-0.60)$ \\
\hline
\end{tabular}

D

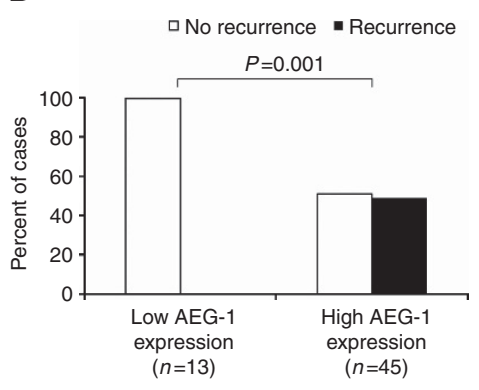

E

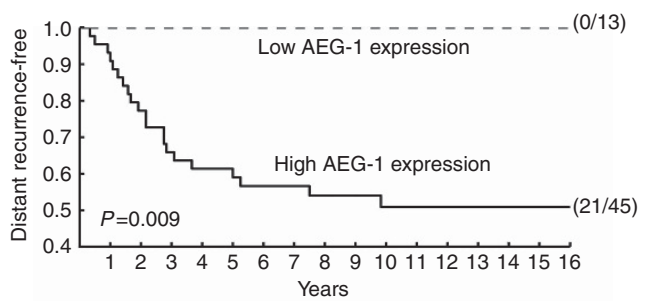

\begin{tabular}{|c|c|c|}
\hline Patient at risk & 5 years & 10 years \\
\hline Low AEG-1 & 10 & 6 \\
\hline High AEG-1 & 25 & 17 \\
\hline Cumulative survival $(95 \% \mathrm{Cl})$ & & \\
\hline Low AEG-1 & $0.00(0.00-0.31)$ & $0.00(0.00-0.46)$ \\
\hline High AEG-1 & $0.59(0.46-0.72)$ & $0.51(0.36-0.66)$ \\
\hline
\end{tabular}

$\mathbf{F}$

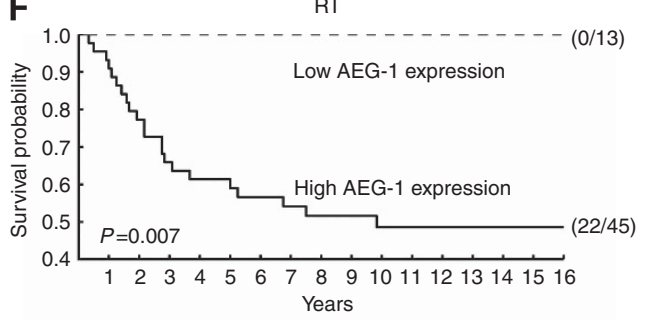

\begin{tabular}{|c|c|c|}
\hline Patient at risk & 5 years & 10 years \\
\hline Low AEG-1 & 10 & 6 \\
\hline High AEG-1 & 25 & 15 \\
\hline Cumulative survival $(95 \% \mathrm{Cl})$ & & \\
\hline Low AEG-1 & $0.00(0.00-0.31)$ & $0.00(0.00-0.46)$ \\
\hline High AEG-1 & $0.55(0.40-0.70)$ & $0.49(0.33-0.65)$ \\
\hline
\end{tabular}

Figure 3. The AEG-1 expression in relation to distant recurrence and disease-free survival. In the non-RT group, the AEG-1 expression was not related to $(\mathbf{A})$ total recurrence, $(\mathbf{B})$ distant recurrence rate, or $(\mathbf{C})$ disease-free survival $(P>0.05)$. In the RT group, tumour with a high $A E G-1$ expression had a significantly higher risk of developing (D) recurrence $(P=0.001)$, (E) a significantly higher distant recurrence rate $(P=0.009)$, and (F) a worse disease-free survival $(P=0.007)$. The patient numbers are presented in parentheses. Patients at risk and cumulative survival estimates with $95 \%$ confidence interval $(\mathrm{Cl})$ are given at 5 and 10 years after surgery.

(32\% vs 33\%; $P=0.89$; Figure $4 \mathrm{D}$ and $\mathrm{E}$ ). To confirm the results we repeated the experiment lasting 10 days with stable AEG-1 knockdown cells for the cell lines SW480, SW620, and HCT116. We found decreased survival for the SW480 and SW620 AEG-1 knockdown cells compared with negative control, similar as with the transient setting after 2 Gy radiation. However, stable HCT116 AEG-1 knockdown cells had an increased survival upon radiation (Supplementary Figures 3 and 4).

Upregulation of AEG-1 in the cell lines KM12C and KM12L4a showed no differences in survival compared with the negative control after 2, 4, and 6 Gy radiation, respectively $(P>0.05$, Supplementary Figure 2).

\section{DISCUSSION}

The present study is the first analysing AEG-1 expression in relation to RT as well as to the clinical outcome in rectal cancer patients. In addition, for the first time, the impact of AEG-1 as a possible radiosensitising target in colon cancer cell lines was investigated.

Previously, we showed that the AEG-1 expression at the mRNA and protein levels significantly increases in CRC from the normal mucosa to the primary tumour (Gnosa et al, 2012). Moreover, we found that AEG-1 expression was not related to patient survival in CRC (Gnosa et al, 2012). Further survival analysis on the same cohort revealed no correlation of the AEG-1 expression with survival in either colon cancer patients or in rectal cancers patients (S Gnosa, unpublished data). In this study we confirm our previous findings. The AEG-1 expression increased in both the non-RT and RT groups, from the distant and adjacent normal mucosa to the primary tumour. In addition, three out of five colon cancer cell lines showed higher expression of AEG-1 compared with normal colon cell lines. Furthermore, there was no relationship of the AEG-1 expression with patient survival in the non-RT group. 
Table 1. AEG-1 expression in the primary rectal tumour in relation to biological variables

\begin{tabular}{|c|c|c|c|c|c|c|}
\hline \multirow[b]{3}{*}{ Variables } & \multicolumn{2}{|c|}{ Non-RT } & \multicolumn{3}{|c|}{ RT } & \multirow[b]{3}{*}{$P$-value } \\
\hline & \multicolumn{2}{|c|}{ AEG-1 intensity } & \multirow[b]{2}{*}{$P$-value } & \multicolumn{2}{|c|}{ AEG-1 intensity } & \\
\hline & Low (\%) & High (\%) & & Low (\%) & High (\%) & \\
\hline Mac30 & & & 0.021 & & & 0.11 \\
\hline $\begin{array}{l}\text { Low } \\
\text { High }\end{array}$ & $\begin{array}{l}6(13) \\
7(39)\end{array}$ & $\begin{array}{l}40(87) \\
11(61)\end{array}$ & & $\begin{array}{l}8(20) \\
4(44)\end{array}$ & $\begin{array}{r}33(80) \\
5(56)\end{array}$ & \\
\hline Ki-67 & & & 0.026 & & & 0.43 \\
\hline $\begin{array}{l}\text { Low } \\
\text { High }\end{array}$ & $\begin{array}{r}10(34) \\
4(11)\end{array}$ & $\begin{array}{l}19(66) \\
31(89)\end{array}$ & & $\begin{array}{l}6 \text { (21) } \\
6(46)\end{array}$ & $\begin{array}{l}22(79) \\
13(54)\end{array}$ & \\
\hline FXYD-3 & & & 0.62 & & & 0.016 \\
\hline $\begin{array}{l}\text { Low } \\
\text { High }\end{array}$ & $\begin{array}{l}7(25) \\
8(20)\end{array}$ & $\begin{array}{l}21(75) \\
32(80)\end{array}$ & & $\begin{array}{l}9(41) \\
4(12.5)\end{array}$ & $\begin{array}{l}13(59) \\
28(87.5)\end{array}$ & \\
\hline Lox & & & 0.99 & & & 0.037 \\
\hline $\begin{array}{l}\text { Low } \\
\text { High }\end{array}$ & $\begin{array}{l}8(17) \\
5(17)\end{array}$ & $\begin{array}{l}38(83) \\
24(83)\end{array}$ & & $\begin{array}{l}9(32) \\
3(10)\end{array}$ & $\begin{array}{l}19(68) \\
27(90)\end{array}$ & \\
\hline Livin & & & $<0.001$ & & & $<0.001$ \\
\hline $\begin{array}{l}\text { Low } \\
\text { High }\end{array}$ & $\begin{array}{c}10(48) \\
3(6) \\
\end{array}$ & $\begin{array}{l}11(52) \\
51(94) \\
\end{array}$ & & $\begin{array}{r}10(50) \\
4(10) \\
\end{array}$ & $\begin{array}{l}10(50) \\
37(90) \\
\end{array}$ & \\
\hline
\end{tabular}
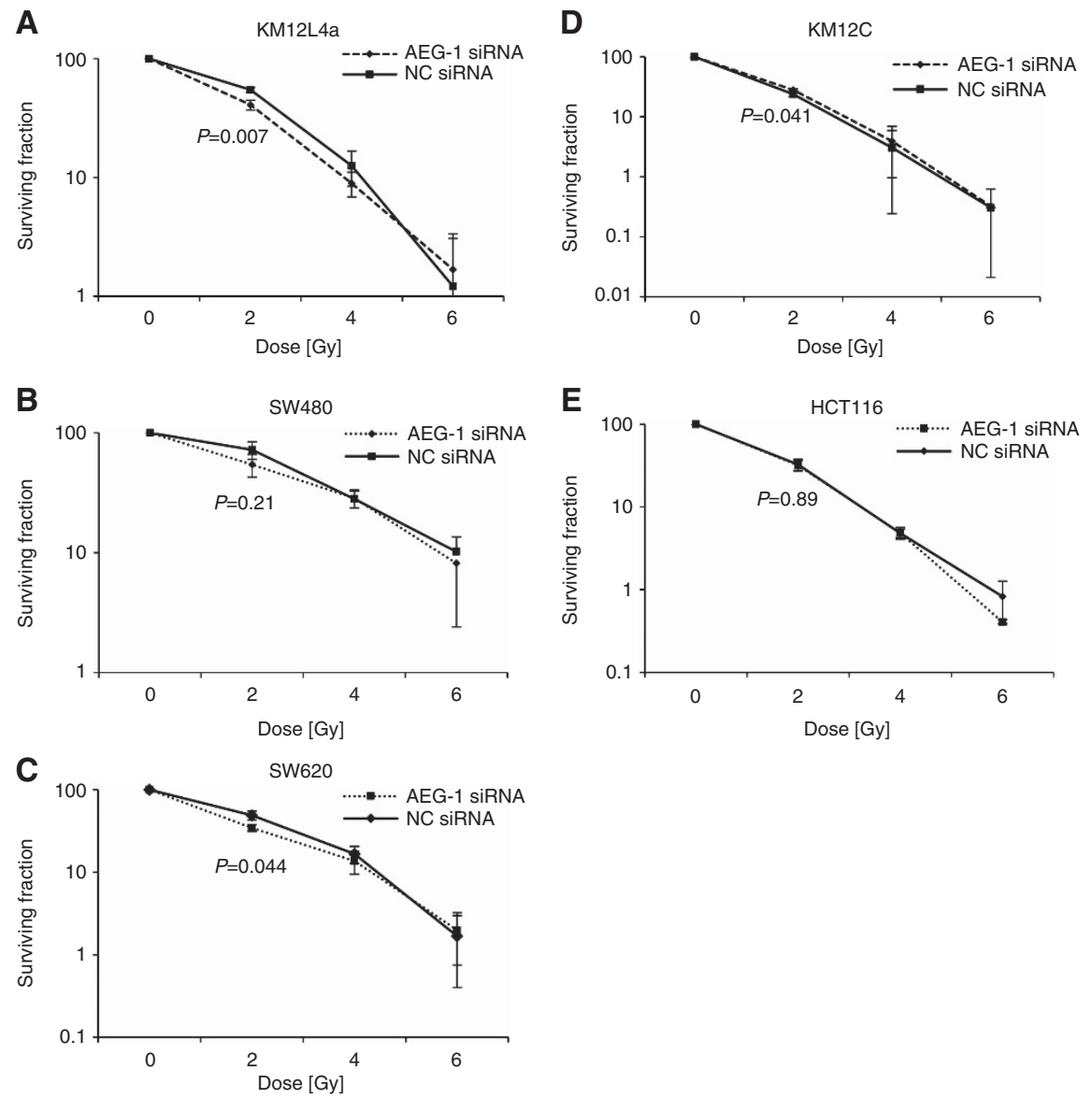

Figure 4. Colony-forming assay of the cell lines (A) KM12L4a, (B) SW480, (C) SW620, (D) KM12C, and (E) HCT116 treated with AEG-1 siRNA or negative control siRNA and increased radiation doses. The AEG-1 knockdown had a radiosensitising effect in the cell lines KM12L4a $(P=0.001)$, SW480 $(P=0.21)$, and SW620 $(P=0.044)$ after 2 Gy radiation. In the cell line KM12C, the survival increased in the AEG-1 knockdown cells after $2 \mathrm{~Gy}$ radiation compared with the negative control $(P=0.041)$, whereas no change was seen in the HCT116 cell line $(P=0.89)$. 
Despite the involvement of AEG-1 in CRC development independently of RT, we found that tumours treated with RT expressing high levels of AEG-1 correlated to a higher risk of distant recurrence and to worse disease-free survival independently of the tumour stage. Studies by others have shown an involvement of AEG-1 in migration and invasion in various kinds of cancer (Emdad et al, 2006; Kikuno et al, 2007; Emdad et al, 2010; Zhang et al, 2013). AEG-1 overexpression in HeLa, human hepatocellular carcinoma, neuroblastoma, and CREF cells showed an increased matrix invasion, an indicator for increased metastatic ability (Emdad et al, 2006; Emdad et al, 2009; Lee et al, 2009; Yoo et al, 2009). In vivo studies using nude mice xenograft models of human hepatocellular cells showed that overexpression of AEG-1 resulted in highly aggressive and metastatic tumours, whereas the inhibition of AEG-1 abrogated this effect (Yoo et al, 2009; Srivastava et al, 2012). Another study in breast cancer showed that AEG-1 overexpression augmented metastasis in vivo (Brown and Ruoslahti, 2004). Previously, we found an increased AEG-1 expression in metastases compared with the primary tumours in both patient samples and colon cancer cell lines (Gnosa et al, 2012). We speculate that the increased distant recurrence rate after radiation in high-AEG-1-expressing tumours could be because of the metastasis-promoting properties of AEG-1.

In the present study we also analysed the relationship between the AEG-1 expression and other factors analysed on the same cohort at our laboratory. In the non-RT group, we found a negative correlation of the AEG-1 expression to the Mac30 and a positive correlation to the Ki-67 expression. Mac30 was previously shown to be activated by BRCA1 and downregulated by the C-jun N-terminal kinase and p53. The Mac30 expression was related to the development and aggressiveness of the tumour as well as to the patient survival in CRC (Moparthi et al, 2007). Ki-67, a welldescribed proliferation factor, is expressed during all active phases of the cell cycle, and a low Ki-67 expression correlates to a pronounced effect of RT (Adell et al, 2001). Only in the RT group, a positive correlation was found between the AEG-1 expression with both FXYD-3 and Lox expression. The FXYD-3, also called MAT8, is a member of the family of small membrane proteins (Bibert et al, 2006). It is suggested that FXYD-3 participates in the circumstancedependent cellular proliferation or antiproliferation, and high FXYD-3 expression was associated with a worse survival in rectal cancer patients only in the RT group (Arimochi et al, 2007; Loftås et al, 2009). Lox, a matrix-modifying enzyme, has been linked to CRC progression, in particular to invasion and metastasis (Kagan and Trackman, 1991; Baker et al, 2011). However, the biological background of the relationship between AEG-1 and those factors is still unclear and needs to be further investigated.

Taken together, we showed that AEG-1 expression increased during rectal cancer development and was independently related to the distant recurrence and disease-free survival in rectal cancer patients with RT, making it a marker to discriminate patients for distant relapse after RT.

Recently, Zhao et al (2012) showed a possible involvement of AEG-1 in radiation response in the cervical cancer cell line SiHa. The AEG-1 knock-down resulted in a decreased survival and G2 phase arrest after radiation as well as in radiation-induced apoptosis in those cells. Furthermore, they suggested AEG-1 to be a possible predictive marker for radiation response in cervical cancer. In the present study we therefore inhibited AEG-1 expression by siRNA in five colon cancer cell lines and analysed the clonogenic survival after radiation. We found that AEG-1 knockdown had a radiosensitising effect in the cell lines KM12L4a, SW480, and SW620. Those cell lines are often referred to as radioresistant cells in the literature (Rödel et al, 2005; Pfeifer et al, 2009; Shin et al, 2012). However, AEG-1 knockdown in the cell lines KM12C and HCT116 showed an increased survival. In concordance to previous studies (Pfeifer et al, 2009; Kobunai et al, 2011) these cells had a very high sensitivity to radiation already from start (28\% and $33 \%$ respectively after $2 \mathrm{~Gy})$. Furthermore, we found in the studied cell lines that high endogenous AEG-1 levels correlated to a high RT sensitivity, but further studies are needed to understand the radiosensitising properties of AEG-1.

In conclusion, this study showed that AEG-1 expression was independently related to distant recurrence and disease-free survival in rectal cancer patients treated with RT. Together with the findings obtained in the cell lines in this study, AEG-1 may be considered as a promising radiosensitising target for rectal cancer.

\section{ACKNOWLEDGEMENTS}

We are thankful to Dr Peter Larsson, Dr Alexandru Dasu, Mrs Frida Åstrand, and Mrs Emelie Adolfsson (Department of Medical and Health Sciences, University of Linköping, Linköping, Sweden) for helping us in radiating the cells. We thank Dr Janine Erler (Section of Cell and Molecular Biology, The Institute of Cancer Research, London, UK) for providing the data of Lox expression, Dr Richard Palmqvist (Umeå University, Sweden) for providing the CCD-18Co cell line, and Dr Liang Xu for the CCD-841 CoN cell line (University of Kansas, Lawrence, KS). The study was supported by grants from the Swedish Cancer Foundation, Swedish Research Council, and the Health Research Council in South-East Sweden.

\section{CONFLICT OF INTEREST}

The authors declare no conflict of interest.

\section{REFERENCES}

Adell G, Zhang H, Jansson A, Sun XF, Stål O, Nordenshjöld B (2001) Decreased tumor cell proliferation as an indicator of the effect of preoperative radiotherapy of rectal cancer. Int J Radiat Oncol Biol Phys 50: 659-663.

Arimochi J, Ohashi-Kobayashi A, Maeda M (2007) Interaction of Mat-8 (FXYD-3) with $\mathrm{Na}+/ \mathrm{K}+-$ ATPase in colorectal cancer cells. Biol Pharm Bull 4: 648-654.

Baker AM, Cox TR, Bird D, Lang G, Murray GI, Sun XF, Southall SM, Wilson JR, Erler JT (2011) The role of lysyl oxidase in SRC-dependent proliferation and metastasis of colorectal cancer. J Natl Cancer Inst 5: 407-424.

Bibert S, Roy S, Schaer D, Felley-Bosco E, Geering K (2006) Structural and functional properties of two human FXYD3 (Mat8) isoforms. J Biol Chem 281: 39142-39151.

Brown DM, Ruoslahti E (2004) Metadherin, a cell surface protein in breast tumors that mediates lung metastasis. Cancer Cell 5: 365-374.

Chen W, Ke Z, Shi H, Yang S, Wang L (2010) Overexpression of AEG-1 in renal cell carcinoma and its correlation with tumor nuclear grade and progression. Neoplasma 57: 522-529.

Collet D (1994) Modeling Survival Data in Medical Research. Chapman \& Hall: London.

Ding ZY, Zhang H, Adell G, Olsson B, Sun XF (2013) Livin expression is an independent factor in rectal cancer patients with or without preoperative radiotherapy. Radiat Oncol 6: 281.

Emdad L, Lee SG, Su ZZ, Jeon HY, Boukerche H, Sarkar D, Fisher PB (2009) Astrocyte elevated gene-1 (AEG-1) functions as an oncogene and regulates angiogenesis. Proc Natl Acad Sci USA 106: 21300-21305.

Emdad L, Sarkar D, Lee SG, Su ZZ, Yoo BK, Dash R, Yacoub A, Fuller CE, Shah K, Dent P, Bruce JN, Fisher PB (2010) Astrocyte elevated gene-1: a novel target for human glioma therapy. Mol Cancer Ther 9: 79-88.

Emdad L, Sarkar D, Su ZZ, Randolph A, Boukerche H, Valerie K, Fisher PB (2006) Activation of the nuclear factor kappaB pathway by astrocyte elevated gene-1: implications for tumour progression and metastasis. Cancer Res 66: 1509-1516. 
Ferlay J, Shin HR, Bray F, Forman D, Mathers C, Parkin DM (2010) Estimates of worldwide burden of cancer in 2008: GLOBOCAN 2008. Int J Cancer 127: 2893-2817.

Gnosa S, Shen YM, Wang CJ, Zhang H, Stratmann J, Arbman G, Sun XF (2012) Expression of AEG-1 mRNA and protein in colorectal cancer patients and colon cancer cell lines. J Transl Med 10: 109.

Huerta S, Gao X, Saha D (2009) Mechanisms of resistance to ionizing radiation in rectal cancer. Expert Rev Mol Diagn 9: 469-480.

Jian-bo X, Hui W, Yu-long H, Chang-hua Z, Long-juan Z, Shi-rong C, Wen-hua Z (2011) Astrocyte-elevated gene-1 overexpression is associated with poor prognosis in gastric cancer. Med Oncol 28: 455-462.

Kagan HM, Trackman PC (1991) Properties and function of lysyl oxidase. Am J Respir Cell Mol Biol 3: 206-210.

Kapiteijn E, Marijnen CA, Nagtegaal ID, Putter H, Steup WH, Wiggers T, Rutten HJ, Pahlman L, Glimelius B, van Krieken JH, Leer JW, van de Velde CJ (2001) Preoperative radiotherapy combined with total mesorectal excision for resecable rectal cancer. N Engl J Med 354: 638-646.

Kikuno N, Shiina H, Urakami S, Kawamoto K, Hirata H, Tanaka Y, Place RF, Pookot D, Majid S, Igawa M, Dahiya R (2007) Knockdown of astrocyteelevated gene-1 inhibits prostate cancer progression through upregulation of FOXO3a activity. Oncogene 26: 7647-7655.

Kobunai T, Watanabe T, Fukusato T (2011) REG4, NEIL2, and BIRC5 gene expression correlates with gamma-radiation sensitivity in patients with rectal cancer receiving radiotherapy. Anticancer Res 31: 4147-4153.

Lee SG, Jeon HY, Su ZZ, Richards JE, Vozhilla N, Sarkar D, Van Mearken T, Fisher PB (2009) Astrocyte elevated gene-1 contributes to the pathogenesis of neuroblastoma. Oncogene 28: 2476-2484.

Lee SG, Su ZZ, Emdad L, Sarkar D, Fisher PB (2006) Astrocyte elevated gene-1 (AEG-1) is a target gene of oncogenic Ha-ras requiring phosphatidylinositol 3-kinase and c-Myc. Proc Natl Acad Sci USA 103: 17390-17395.

Lee SG, Su ZZ, Emdad L, Sarkar D, Franke TF, Fisher PB (2008) Astrocyte elevated gene-1 activates cell survival pathways through PI3K-Akt signaling. Oncogene 27: 1114-1121.

Li J, Zhang N, Song LB, Liao WT, Jing LL, Gong LY, Wu J, Yuan J, Zhang HZ, Zeng MS, Li M (2008) Astrocyte eleveated gene-1 is a novel prognostic marker for breast cancer progression and overall patient survival. Clin Cancer Res 14: 3319-3326.

Loftås P, Onnesjö S, Widegren E, Adell g, Kayed H, Kleef J, Zentgraf H, Sun XF (2009) Expression of FXYD-3 is an independent prognostic factor in rectal cancer patients with preoperative radiotherapy. Int J Radiat Oncol Biol Phys 75: 137-142.

Moparthi SB, Arbman G, Wallin Å, Kayed H, Kleeff J, Zentgraf H, Sun XF (2007) Expression of MAC30 protein is related to survival and biological variables in primary and metastatic colorectal cancer. Int J Oncol 30: 91-95.

Pfeifer D, Wallin A, Holmlund B, Sun XF (2009) Protein expression following gamma-irradiation relevant to growth arrest and apoptosis in colon cancer cells. J Cancer Res Clin Oncol 135: 1583-1592.

Påhlman L (2005) Indications for neoadjuvant long-term radiotherapy. Recent Results Cancer Res 65: 212-220.

Rödel F, Hoffmann J, Distel L, Herrmann M, Noisterniq T, Papadopoulos T, Sauer R, Rödel C (2005) Survivin as a radioresistance factor, and prognostic and therapeutic target for radiotherapy in rectal cancer. Cancer Res 65: 4881-4887.
Sarkar D, Park ES, Emdad L, Lee SG, Su ZZ, Fisher PB (2008) Molecular basis of nucelear factor-kappaB activation by astrocyte elevated gene-1. Cancer Res 68: 1478-1484.

Shin JS, Foo T, Hong A, Zhang M, Lum T, Solomon MJ, Lee CS (2012) Telomerase expression as a predictive marker of radiotherapy response in rectal cancer. Pathology 44: 209-215.

Song L, Li W, Zhang H, Liao W, Dai T, Yu C, Ding X, Zhang L, Li J (2009) Over-expression of AEG-1 significantly associates with tumour aggressiveness and poor prognosis in human non-small cell lung cancer. J Pathol 219: 317-326.

Srivastava J, Siddig A, Emdad L, Santhekadur PK, Chen D, Gredler R, Shen XN, Robertson CL, Dumur CI, Hylemon PB, Mukhopadhyay ND, Bhere D, Shah K, Ahmad R, Giashuddin S, Stafflinger J, Subler MA, Windle JJ, Fisher PB, Sarkar D (2012) Astrocyte elevated gene-1 promotes hepatocarcinogenesis: novel insights from a mouse model. Hepatology 56: 1782-1791.

Su ZZ, Kang DC, Chen Y, Pekarskaya O, Chao W, Volsky DJ, Fisher PB (2002) Identification and cloning of human astrocyte genes displaying elevated expression after infection with HIV-1 or exposure to HIV-1 envelope glycoprotein by rapid subtraction hybridization, RaSH. Oncogene 21: 3592-3602.

Swedish Rectal Cancer Trial (1997) Improved survival with preoperative radiotherapy in resectable rectal cancer. $N$ Engl J Med 336: 980-987.

Thirkettle HJ, Girling J, Warren AY, Mills IG, Sahadevan K, Leung H, Hamdy F, Whitaker HC, Neal DE (2009) LYRIC/AEG-1 is targeted to different subcellular compartments by ubiquitinylation and intrinsic nuclear localization signals. Clin Cancer Res 15: 3033-3313.

Yoo BK, Emdad L, Lee SG, Su ZZ, Santhekadur P, Chen D, Gredler R, Fisher PB, Sarkar D (2011) Astrocyte elevated gene-1 (AEG-1): a multifunctional regulator of normal and abnormal physiology. Pharmacol Ther 130: 1-8.

Yoo BK, Emdad L, Su ZZ, Villanueva A, Chiang DY, Mukhopadhyay ND, Mills AS, Waxman S, Fisher RA, Llovet JM, Fisher PB, Sarkar D (2009) Astrocyte elevated gene-1 regulates hepatocellular carcinoma development and progression. J Clin Invest 119: 465-477.

Yu C, Chen K, Zheng H, Guo X, Jia W, Li M, Zeng M, Li J, Song L (2009) Overexpression of astrocyte elevated gene-1 (AEG-1) is associated with esophageal squamous cell carcinoma (ESCC) progression and pathogenesis. Carcinogenesis 30: 894-901.

Zhang F, Yang Q, Meng F, Shi H, Li H, Liag Y, Han A (2013) Astrocyte elevated gene- 1 interacts with $\beta$-catenin and increases migration and invasion of colorectal carcinoma. Mol Carcinog 52: 603-610.

Zhang ZY, Zhao ZR, Adell G, Jarlsfelt I, Cui YX, Kayed H, Kleef J, Wang MW, Sun XF (2006) Expression of MAC30 in rectal cancer with or without preoperative radiotherapy. Oncology 71: 259-265.

Zhao Z, Moran MS, Yang Q, Liu Q, Yuan C, Hong S, Kong B (2012) Metadherin regulates radioresistance in cervical cancer cells. Oncol Rep 27: $1520-1526$.

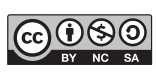

This work is licensed under the Creative Commons Attribution-NonCommercial-Share Alike 3.0 Unported License. To view a copy of this license, visit http://creativecommons. org/licenses/by-nc-sa/3.0/

Supplementary Information accompanies this paper on British Journal of Cancer website (http://www.nature.com/bjc) 